\title{
BREACH OF ONE INSTALLMENT OF A DIVISIBLE CONTRACT.
}

\section{(Concluded.)}

It was not until 1884 that this question was presented to the House of Lords in Mersey Co. v. Naylor et al., L. R., 9 App. Cases 434. This case is peculiar both in its facts and the opinions therein delivered.

The facts are fully set forth in the report of the decision of the case in the Court of Appeals, L. R., 9 Q. B. D. 648. They were as follows: Naylor \& Co., the defendants, agreed to purchase 5,000 tons of steel blooms to be delivered at Liverpool in monthly installments of $I, 000$ tons, payment within three days after receipt of shipping documents.

The plaintiff's company delivered in January one-half the first installment, but before payment became due a petition was presented to wind up the company. The defendants were advised by their solicitors that they could not, without leave of the Court, safely pay the company pending the petition and asked the company to obtain an order sanctioning the payment. This the company refused to do, and notified the defendants that they would treat the failure to pay as a breach, terminating the entire contract. The case being tried before Coleridge, C. J., he held that there had been a refusal to pay, which amounted to a repudiation of the contract, and gave the plaintiffs the right to rescind, saying: "Here the defendants, while insisting upon future deliveries, positively refused to pay for the iron already delivered, and for all which might subsequently be delivered, unless the plaintiffs fulfilled a condition which the defendants in my opinion had no right to impose." In other words, the refusal to pay, if a real refusal at all; related not merely to the amount due for the iron already delivered, but for all which might be delivered during the pendency of the petition, which might, though in fact it did not, include several future deliveries, and so was as much a breach by anticipation as to such pos- 
sible future deliveries as it was already an actual breach as to the previous installment.

The decision was overruled by the Court of Appeals, and it is submitted that the more attentive the study of the case the more certain will be the conviction that this action was based upon the different view taken by the upper Court as to the failure to pay, not upon any difference as to the effect of such a "positive refusal" as Coleridge conceived to exist.

All the judges refused to call the defendants' failure to pay, either what was due or what might become due for iron deliverable in future, a refusal, terming it rather "a demur, a delay, a postponement." Selborne, L. J. "a hesitation." Lindley. L. J., p. 666, held that so far from evidencing an intention to repudiate the contract as entered into, it showed on the defendants' side an embarrassment as to the possibility of carrying it out, and suggesting a mode of obviating it; in a word, so far from showing a clesire to escape performance, it showed rather an earnest effort to do so. ${ }^{1}$

The judges all quoted and approved the rule in Freeth v. Burr to this extent, $i$. $e$., where the actual default showed no intent to evade any obligation under the contract, it could not amount to a breach thereof, though in fáct rendered an exact literal performance impossible.

It is the relative conduct of the two parties which weighed with the Court - the defendants, though guilty of a technical breach, desirous of performing their contract if the plaintiffs will only aid them; the plaintiffs earnestly desirous of escaping from a losing bargain. All the opinions leave open the question of the effect of a positive refusal to pay; it is upon the special circumstances that the Court bases its decision.

The House of Lords sustained the action of the Court below, and here again is observable the same preponderating weight attached to the character of the failure to pay as being a mere demur-hesitation, etc., and as not amounting to a positive refusal to carry out a term of the contract-

\footnotetext{
${ }^{1}$ Sir Charles Russell, now Chief Justice: "The question is, whether there is such a refusal to abide by a material term of the contract as ought to be treated as a refusal to perform the contract." p. 655 .
} 
and the same care to restrict the effect of the decision to its own facts, and to leave untouched the effect of an absolute unexplained refusal to perform a term of the contract.

On a close inspection of the opinions the various judges appear to differ on almost every point, and yet arrive finally at a unanimous decision of the case.

Lord Selborne held the contract to be entire. Lord Blackburn practically held it to be a group of separate contracts, a breach of any of which could affect the others only so far as it evidenced an intention to refuse future performance. such as would amount to a breach by anticipation thereof. Lord Selborne refused to discuss the earlier cases. approving and applying the rule of Freeth v. Burr as he understood it. Lord Blackburn distinguished them as cases where the Court, apparently to his mind erroneously, had held the delivery of a certain amount per month to go to the root of the consideration," while Lord Bramwell says "he could not tell why Hoare v. Rennie and Houck v. Muller have been brought forward as bearing on the case in hand."

Lord Blackburn, while approving of Freeth v. Burr, understood it as an application of the doctrine of breach by anticipation to divisible contract, stating it to be of the same effect as Hochster v. de la Tour, 2 El. \& Bl. 678 (the leading case on that subject), while Lord Selborne took it to be that even though the breach be not of a condition precedent, if the conduct of the party "amount to a renunciation, to an absolute refusal, to perform the contract," ${ }^{2}$ then the party aggrieved may accept it as reason for not performing his part; in other words, did the circumstances surrounding the breach show any desire to avoid any of the obligations of the contract, or indicate any inability to perform it as a whole, and considering this to be the rule, he, in a critical analysis of the facts, held that the defendants' conduct so far from indicating a desire to avoid any of its

${ }^{1}$ As before pointed out in Hoare $v$. Rennie, the Court refused to allow the question to be argued, and in Bowes $\%$. Shand, Lord Blackburn himself held all stipulations as to time and mode of performance to be essential.

${ }^{3}$ The contract entire, as he afterward states it to be not of the residue alone. 
obligations, on the contrary showed them to be desirous of doing all in their power to fulfill them as fully as was possible; an exact performance being put out of the question by their honest mistake as to the company's power to accept and reccipt for a payment when due.

Upon only two points is there any practical unanimity of opinion: ( $I$ ) that thedefendants"conductheredid notamount to an absolute refusal to perform their contract, but was a mere hesitation or demur caused by an honest reliance upon mistaken legal advice, and that they in fact, so far from desiring to evade any of their obligations under their contract, were able and anxious to fulfill them, and were suggesting means whereby the difficulty might be escaped; and (2) that the judges and law lords were most careful to restrict their decision to the facts in hand, and to leave untouched the effect of an absolute refusal to pay for any one installment. ${ }^{1}$

How far is this case decisive? Does it decide with Lord Blackburn that the contract is not entire, or with Lord Selborne that it is? Is it not, after all, in view of the conflict of views expressed, authority only as its own facts or at furthest facts so similar as to indicate, as also in Freeth v. Burr, ${ }^{2}$ L. R., 9 C. P. 208, that the breach is but technical, that the party in fault does not wish to repudiate, or escape from any of his obligations, but is honestly desirous to fulfill them all exactly, and still able to do so in substantial though of course not exact accordance with all of the stipulations of the contract, notwithstanding the technical breach which he has committed, owing to an honest mistake or to some extraordinary position in which he may find himself placed, without fault on his part? All beyond this would appear mere dicta, and, as has been seen, conflicting dicta at that.

${ }^{1}$ Lord Blackburn seems to consider an absolute refusal to pay for one installment could only be of effect as an indication of an intent to refuse future payments, but, as Lord Coleridge pointed out, the refusal here, if a refusal at all, relates to some, if not all, the future installments.

${ }^{2}$ Where the party refused payment for one installment because of prior delays, claiming the right to hold back one payment to secure himself against future delays, but always announced his intention of finally paying all due. 
Undoubtedly in this case justice was clone. The plaintiff company had attempted to escape from a losing contract by alleging that it was ended by a technical breach committed by parties earnestly desirous of keeping it in force and anxious to arrive at some way whereby they could cariy out their part with safety to themselves; and if it be restricted as authority to its own facts, little can be said in criticism of it as a decision upon the merits of the contestants.

It, however, is open to the same objections urged against Freeth v. Burr, though perhaps to a less extent, more effect being given to the character of the defendants conduct in this case as not amounting to a real refusal, a true breach at all.

Like it, it allows the character of a default to set aside the intention of the parties as expressed in their contract. Sympathy for the hard position of a party innocently in honest difficulties as to how he may safely perform his contract, overrides the necessity for certainty universally recognized as the first essential in commercial contract. In a word, while good justice if restricted to its own facts, it is perilously near bad law.

Scientifically there would seem to be but two positions possible:

That taken in Hoare v. Remicie ${ }^{1}$ and Houck v. Miller, ${ }^{2}$ that the contract being entire, a breach of any part thereof entitles the party aggrieved to terminate so much of the contract as remains executory, and that indicated by Lord Blackburn in Mersey v. Naylor, that such contracts are to be construed not as intended to be one entire contract, but rather as separate contracts for each installment to be performed without relation to one another in one instrument, where of course a breach of one can only affect the others when the conduct of the party committing the breach amounts to a breach by anticipation of the others.

Both give effect to the intention of the parties as it appears to the Court from an inspection of the contract; they differ only in the construction placed by the Court upon the con-

${ }^{2} 5$ H. \& N. Ig.

'L. R., 7 Q. B. D. 92. 
tract. Lord Blackburn indicates that such contracts may show an intent under exceptional circumstances to regard the various parts of the contract as essential one to the other, the performance of each as vital to the full enjoyment of all; but he indicates that, as a rule, he would hold each installment as intended to be capable of being performed or broken without affecting the value of the performance of the rest.

As a rule of construction the former appears obviously the more accurate, besides having the support of the weight of authority, including the opinion of Lord Selborne in Mersey v. Naylor. The contract is usually for an entire amount. the division of performance relating only to the time and mode of performance. If the parties intended the contract to be not divisible but divided, it would have been the most simple and obvious plan to draw as many separate contracts as there were to be deliveries, or in some other way indicate that each delivery is without relation to the rest; and last, but most important, a form of contract, apparently not only the best, but the only form appropriate to provide for a constant and regular and orderly supply of goods or market therefor, is taken to mean exactly the contrary, that any amount delivered will be gladly accepted, any amount the vendee may choose to take will be sold.

The contract on its face appears to be for an entire amount. The form is one which appears admirably designed to provide for the sale or purchase of a large amount of goods, while allowing the vendor to provide from the receipts for one delivery, the goods to be afterwards delivered, or the vendee, by the sale of the first installment, to prepare for the payment of the rest, to enable merchants to make sure of a regular supply for the future without having to carry an unnecessarily large stock on hand, or of a market for the future without providing goods perhaps beyond their present capacity; in a word, to provide with certainty for the future without overstraining their present resources, and so to turn over their capital the more quickly. To hold that by such a form of contract they intend that they will supply or accept any one or more installments without relation to the others is to render useless this form of contract.

Of the two views, that of Lord Bramwell in Houck v. 
Miller seems by far the better; nor, as has been pointed out, would the case of Mersey v. Naylor prevent the application thereof to future English cases, save when similar exceptional circumstances existed; and this view of the construction of such contracts, and the effect thereon of an absolute breach of any one installment, has the support of all but a very small minority of the American Courts. ${ }^{1}$

Some slight confusion has resulted from an attempt by Mr. Justice Gray to reconcile the English cases, as has been seen hopelessly conflicting, as they are, by a distinction between the effect of a failure to deliver and a failure to pay for one installment.

This attempted distinction is based on a dictum ${ }^{2}$ by Lord Selborne in Mersey v. Naylor, and with all deference to Mr. Justice Gray, it is stibmitted upon a mistaken view of the dictum in question. ${ }^{2}$

In Lord Selborne's opinion-it was the order of performance, not the character of it, which prevented the payment from being a condition precedent-he makes no distinction between a failure to pay and a failure to deliver; but he says that since payment for each installment must be after delivery, it cannot be a condition precedent to that part, and what cannot be a condition precedent of a part cannot be of the whole. Had it been agreed that payment should precede delivery, this same reasoning would make payment a condition precedent; and prevent a delivery of one portion being a condition to the right to demand the future payment.

The leading case in the United States is that of Norrington v. Wright, $\mathrm{x}_{5} \mathrm{U}$ U. S. $\mathrm{x} 88$. The plaintiff had agreed to sell 5,000 tons of iron to be shipped at the rates of "about" $\mathrm{I}, 000$ tons a month, beginning February Ist, the whole to

${ }^{1}$ The case of Gerti $v$. Poidebard, 57 N. J. L. 432, appearing to follow Lord Blackburn's opinion in Mersey $v$. Naylor to its fullest extent.

"It is found on page 439, L. R., 9 App. Cas. He says: "The contract is entire; it is not split by the division of performance into as many contracts as there are to be deliveries." He then says: "It is perfectly clear that no particular payment can be a condition precedent of the entire contract, because delivery was most certainly to precede payment, and that being so, I cannot see how, without express words, it can be made a condition precedent to the subsequent fulfillment of the unfulfilled part of the contract." 
be completed by August Ist. He shipped only 400 in February, 880 in March, $1,57 \mathrm{I}$ in April, 850 in May, 1,000 in June, and in July 300 . The defendants received and paid for the February shipments, being in ignorance that the full $I, 000$ tons would not be shipped in that month; but in May, just before the arrival of the March shipment, hearing for the first time of the amounts shipped in February, March and April, they wrote plaintiff's agents that they would refuse the March and April shipments as not being in accordance to contract, and also refused to receive any future shipments.

On the trial, ${ }^{1}$ which took place before the decision of Mcrscy v. Naylor, the Circuit Court being of opinion that the defendants had the right to rescind, the plaintiff suffered a "non-stit," which the Court refused to take off. Judge Butler, in a very able oral opinion, placing his opinion firmly upon the ground that the contract being entire till divided, performance by one party cannot be demanded till the other has performed or tendered a performance on his side, and that the contract being "severable" did not advance the plaintiff's position-_"to make his position logical, the contract must be held to be not one contract but several clistinct independent contracts;" and while he considers that in Simpson v. Crippin the English Courts have gone thus far, he refuses to adopt their position, but says it is for the Supreme Court to take such a step if they see fit. ${ }^{2}$

${ }^{2} 5$ Fed. Rep. 768.

${ }^{2}$ This opinion so admirably states the view that such contracts must be governed by the ordinary rules of commercial law, that the following rather lengthy extract may perhaps be pardoned: "The right to rescind a contract for non-performance is a remedy as old as the law of contract itself. Where the contract is entire-indivisible-the right is unquestioned. The undertakings on the one side, and on the other, are dependent, and performance by one party cannot be enforced by the other without performance, or a tender of performance, on his own part. In the case before us the contract is 'severable.' But to say it is 'severable' does not advance the plaintiff's argument. A 'severable' contract, as the language imports, is a contract liable simply to be severed. In its origin, and till severed, it is entire, a single bargain or transaction. The doctrine of severableness (if I may be allowed to coin a word) in contracts is an invention of the courts, in the interest of justice, designed to enable 
The Supreme Court upheld the action of the Court below, holding in accordance with Lord Selborne ${ }^{1}$ that the contract was one entire contract, and not split into as many contracts as there were shipments. These subsidiary provisions related to time and mode of performance of the entire contract, and under Bozerers v. Shand, such stipulations are of the essence of a mercantile contract. He held the buyers' acceptance of the February shipment to be no waiver, since done in ignorance that the stipulated quantity had not been shipped in that month, and finally, that the plaintiff, asserting the contract to be still in force, is bound to show such performance on his part as entitles him to demand it on theirs. Unfortunately, in an attempt to reconcile the English cases, a hopeless task, he distinguishes them upon a difference between a failure to deliver and to pay one installment. This is not necessary to the decision mere dictum, based upon what is, it is submitted, as before said. a mistaken view of Lord Selborne's dictum in Mersey v. Naylor.

one who has partially performed, and is entitled on such partial performance to something from the other side, to sustain an action in advance of complete performance,-as where goods are sold to be delivered and paid for in parcels, to enable the seller to recover for the parcels delivered, in advance of completing his undertaking. But this equitable doctrine should not be invoked by one who has failed to perform, for the purpose of defeating the other's right to rescind, and thus to protect himself against the consequences of his own wrong. As against such a party the contract should be treated and enforced as entire. To say, therefore, that the contract is 'severable' does not, I repeat, advance the argument. To render the plaintiff's position logical, it is necessary to take a step forward, and hold that such a transaction (it would not be accurate in this view to call it a contract) constitutes several distinct, independent contracts. Then, of course, it follows that a failure as respects one of several successive deliveries affords no right to rescind in regard to those yet to be made."

${ }^{1}$ In Mersey $v$. Naylor, supra.

${ }^{2}$ Is not Lord Selborne's position this? Since each payment was subsequent to each delivery, the consideration for each delivery was the valid unbroken promise to pay for each the consideration for the whole, the valid unbroken promise to pay for all. So here the vendor has practically obtained his consideration; notwithstanding a technical breach of one promise to pay and a possible anticipatory technical breach of some at least of the future payments, the circumstances show 
Therefore, it is not surprising to find in the case of Cresswell v. Martindale, 63 Fed. Rep. 86, a failure to accept and pay for a large part of one installment of cattle delivered in one month under such a contract for successive monthly deliveries, held-the Court citing and professing to follow Norrington v. Wright-to entitle the vendor to refuse to make any further deliveries under his contract. In this case also the default came not.as to the first installment, but in a later portion after the contract had been in part executed on both sides.

These two cases then establish fully that while a perfect performance of one portion under the contract entitles the party to an equivalent compensation, a failure of a party to deliver or accept or pay for ${ }^{1}$ one installment at any stage of

the vendee able, willing and ever anxious to perform his promise to pay. In other words, the circumstances show that the vendor has obtained substantially the agreed consideration, a valid promise not repudiated nor likely to be broken. Had the default been absolute, a failure to pay, all the vendor would obtain would be a right of action for damages for a broken promise, and not a promise still practically certain of substantial fulfillment, and so such a breach would destroy the consideration for the one and so render it impossible for the whole consideration ever to be received. This view overlooks the fact that the consideration for only the first installment is the promise to pay for it; the consideration for the others, judged by the rules in Pordage $v$. Cole, the promise to pay for it, and a proper orderly payment of the previous portions. An existing promise as to the future and a full performance as to the past.

${ }^{1}$ No distinction is made in the various state courts, except, perhaps, New Jersey, between a failure to deliver and a failure to pay for one installment. See Robson v. Bohn, 27 Minn. 333, and other cases cited in Cresswell Co. $v$. Martindale. It is, however, only in cases of exceptional circumstances like Mersey $v$. Naylor and Freeth $v$. Burr that the effect of a failure to pay or deliver can be different even in England, and that not from any difference in the rule of law, but because it is more easy to substantially perform a technically broken contract, notwithstanding the breach when the default is in payment and not in delivery. Such circumstances have not so far arisen in the American cases-if they did it is possible that rather than allow injustice to a party innocent of wrongful intent, the English rule, though unscientific, might be applied; this, however, is mere conjecture, and it is to be hoped that, in view of the confusion caused by these cases, the hardship of an innocent wrongdoer, if so he may be termed, will not be allowed to override the plain principles of commercial law. 
the contract entitles the other to at once terminate the contract and refuse further performance thereof.

This right of rescission, or rather of treating a breach as terminating once for all a continuing contract, must be at once exercised; if the breach be waived as to the installment wherein it is committed, it can of course not be used as a reason for refusing performance of the residue of the contract; so, if a defective installment be accepted, and retained with knowledge of its imperfection, here, as in Boone v. Eyre, the only remedy for the breach is a cross-action for damages. Having accepted less, the agreed consideration is waived, and in lieu of perfect performance the party is taken to have agreed to accept the less and an action for damages. The default must be treated as a breach for all purposes or none.

Many cases ${ }^{1}$ which are often cited as establishing that a failure as to one installment of a divisible contract will not justify a termination of the whole are but applications of this rule of waiver of breach. And it is owing to this very misconception that the Pennsylvania cases are so often quoted as opposed to Hoare v. Rennie and Norrington v. Wright. ${ }^{2}$

In Reybold v. Voorhees, $30 \mathrm{~Pa}$. I16, the seller of an entire crop of peaches, to be paid for weekly as delivered, was held entitled to refuse to continue deliveries when a balance due at the end of a week was unpaid. Here it is to be noted the default was in payment, not in delivery, and the question is clearly and directly presented and determined according to Hoare v. Rennie.

The next case, Forsyth v. Oil Co., $53 \mathrm{~Pa}$. 168, is somewhat analogous to Freeth v. Burr and Mersey v. Naylor. The contract had been performed with great latitude on both sides, and the vendor meeting the secretary of the vendee company on the street, asked him for payment, which

${ }^{1}$ Such is the case of Jonasohn $v$. Young, 4 Bog. 296 , decided soon after Hoare $v$. Rennie, and often cited as opposed to it, but really turning on the waiver of the breach by knowing acceptance and retention of imperfect performance.

'As in Benjamin on Sales. 
was petulantly refused. The vendor then declared the contract at an end. That day everything due was paid. It was hold that the refusal was more seeming than real, ${ }^{1}$ and that since by mutual consent the contract had been construed liberally, neither party could avail himself of a refusal to perform it strictly as a breach without notifying the other that he intended to insist on a literal compliance with the terms. But the Court recognized that the right to terminate the contract would have existed but for the mutual agreement that a strict performance was not required.

A number of Pennsylvania cases are often considered as opposed to Hoare v. Rennie and Reybold v. Voorhees, and supporting Simpson v. Crippin.

The first is Lucesco Oil Co. v. Brewer, $66 \mathrm{~Pa}$. 35I. There was in that case no question raised as to the right of one party to refuse to continue to perform a contract already broken by the other. The only question was whether the contract was so far entire that a party who had advanced $\$ 7 \mathrm{x}, 000$ out of $\$ 75,000$ promised could not recover because of the failure to advance the whole, and to render certain accounts of oil sold. It was a case where, as in Boone v. Eyre, a party who had accepted and retained the substantial consideration of his contract is seeking to evade paying therefor by alleging that nothing was due till all was performed. It is this point and no other which the Court has in view when it decides that owing to the apportionment of the consideration the contract is severable and not entire, and that it is the character of the consideration and not the nature of the thing done which determines the contract to be either severable or entire. If the contract be apportioned or apportionable, it is severable if not entire. Whether this rule be a good or bad test ${ }^{2}$ whereby to decide as to the

As in Mersey $v$. Naylor.

IIt is submitted that the correct rule is that stated by Agnew, J., in Shinn $v$. Bodine, $60 \mathrm{~Pa}$. I82: "The entirety of a contract depends on the intention of the party and not the divisibility of the subject; the severable nature of the latter may assist in determining the intention, but cannot overcome it when discovered." And in that case this rule was applied to a contract for the delivery of eight hundred tons of coal on board vessels sent by vendee during August and September, at so 
severability, used in this sense, of a contract, it does not touch in any way the question under discussion.

Morgan v. McKee, $77 \mathrm{~Pa}$. 229, is also often considered as supporting Simpson v. Crippin; however, their suit was brought upon three separate agreements, each for 500 barrels of oil. The defendants offered to prove that these three formed part of one entire contract for 4,000 barrels, which was only for convenience split into eight separate agreements, and that the plaintiffs had failed to deliver the fifth installment, which they alleged terminated their obligations as to the remaining three in suit. The Court properly refused the offer, for to so do would have been to vary the written agreements by parol, by showing each to be not itself a contract, but a mere dependent part of a greater contract; besides, the Court held that the i-iendants had not acted promptly upon the discover, and that if they had ever had a right to rescind, they must-be taken by their delay to have waived it, and to have elected to treat the contract as still existing.

This decision again does not touch the main quer;ion at all, but merely decides a point of evidence that where the parties have reduced their contracts to a written form, which on its face shows them to be not merely severable but separate and independent, evidence cannot be given to show they were something quite different; and, secondly, that by undue delay a party is taken to have waived his right to terminate the contract upon such a default.

So Scott v. Kittanning Coal Co., 89 Pa. 23I, also considered by Benjamin and others as supporting Simpson v. Crippin, will be found on inspection to turn upon the retention and use of the very coal the defective quality of which was the breach alleged as terminating the contract. The defendant could have refused the inferior coal, or if the defect was not immediately patent could have returned it when its defects were discovered. If it was retained and used

much a ton. The contract was held to be entire, notwithstanding the price being computed by the ton. There being no intent to sever the performance discoverable from the right to ship in two months the case was not brought within the rule of Brandt $v$. Lawrence (supra, Part I), and there was no right to payment in advance of deliveries of all. 
it ceased to be a breach available to defeat recovery for the payment for that very delivery, and so of course could not be alleged as a ground for terminating the entire contract. By its acceptance and retention it had become a subject for action of damages. It could not be used to defeat any of the plaintiff's rights under the contract. All such effect had been waived by its acceptance and use.

And in Rugg \& Bogan v. Moore, I Io Pa. 242, the last Pennsylvania case directly on the point, the defendant had sold by a parol contract six carloads of grain at a price per bushel. One car arrived, and the accompanying drafts were paid. The plaintiff refused to pay the drafts accompanying the second car until all the cars were received. The defendant then terminated the contract, and refused to deliver the remaining cars. The Supreme Court held that the severability of the contract was to be decided by the jury by an application of the rule in Lucesco v. Brewer, supra. That under the evidence they could not have consistently found it entire, as there was a strong inference that the payment for each car became due upon delivery, so long as the contract remained unbroken, and the vendee had no right to withhold payment till all was delivered; and if the jury had so found, a failure to pay for any one carload without sufficient reason justified the vendor in rescinding his contract, and if the right was exercised promptly the contract was at an end. It was said that it was only where, as in Morgan v. McKee, "the contract consisted of severable distinct and independent parts, each of which could be performed without reference to the other, that a failure to perform one part does not authorize the termination of the contract, and after distinguishing Scott v. Kittanning Coal Co. as indicated supra, Reybold v. Voorhees is quoted as decisive.

This case decides that the term "severable". is understood by that Court, as it is by Judge Butler," not as indicating a group of separate contracts, but a contract where each part is dependent upon the other, until by performance severed from it, differing from an unseverable entire contract only in this: that a strict orderly performance of a part shall en-

In his opinion in Norrington $v$. Wright. 
title the party to compensation in advance of a tender of the whole, since such is the intention of the parties as gathered from the terms of the contract, and it is this intention which must be discovered by the Court, or jury if the contract be by parol, and which, when discovered, must govern. It is well also to note that here the default was not in a failure to deliver, but in a failure to pay for one installment, and that a part had been fully performed on both sides. This did not affect the right to terminate all that remained executory upon the happening of the breach.. ${ }^{1}$

These Pennsylvania cases also show clearly how the right to terminate a contract upon such a breach may be lost: (I) by prior acquiescence in a loose inexact performance. ${ }^{2}$ To then treat a failure to comply with the strict literal stipulations of the contract would be to allow one party to entrap another into a default so as to escape his own obligations. (2) By delay. The right must be asserted immediately after breach, or will be taken to be waived. ${ }^{3}$

(3) By the acceptance and retention of the imperfect performance of one installment, the defect in which is the breach alleged. ${ }^{4}$ The default must be treated as a breach for all purposes or none. It may be waived once for all, or not at all. If a defective performance be accepted it can never be treated as freeing the party accepting from any of his obligations in regard to that installment, or for the future: the default must be remedied by damages. ${ }^{\tilde{j}}$

In New York the case of Pope v. Porter, I02 N. Y. 366, held that a failure to deliver one installment gave the vendee the right to terminate the whole contract. ${ }^{6}$ The term divisible was held properly applicable to contracts wherein a part performance on the one side must be compensated by a corresponding part performance of the other in advance of any possibility of knowing whether the whole will ever be

I Though, of course, the breach did not affect the rights already vested by the perfect prior part performance.

'Forsyth v. Oil Co., $53 \mathrm{~Pa}$. I6r.

'Morgan v. McKee, $77 \mathrm{~Pa} .229$.

'Scott $v$. Kittanning, 89 Pa. 231.

${ }^{5}$ As in Boone v. Eyre, supra, Part I.

The opinion of Finch, J., is well worth attentive study. 
tendered. But this does not mean that a party must accept a part performance in inverse order of his contract, but according to its terms. ${ }^{1}$ The breach in Pope v. Porter was a failure to deliver, but no weight is attached to this fact, and in Clarke v. Garder, 2I N. Y. 339, the same effect is given to a failure to pay for one installment.

The case of Stcphcnison v. Cady, II7 Mass. 6, often quoted upon both sides, is both exceptional in its facts, and is of little authority beyond them in either.

There were three separate contracts, the only connection being that the deliveries of the second were to begin when those of the first were complete. The vendee refused to pay a draft for certain goods delivered under the first contract, unless security was given for the fulfillment of all the contracts; and this was held to be broad enough to be treated as a general refusal to make any further payments, and so a breach by anticipation of the whole of the contracts, citing Withers v. Reynolds, 2 B. \& Ad. 882, and Bloomer v. Bernstein, I. R., 9 C. P. 588. ${ }^{2}$ Here there was not one contract with stipulations as to severance of performance, but three separate contracts without anything to show them to be anything other than they appeared, independent of each other, except that if the delivery of all under the first contract were excused by a breach thereof, there could be no obligation to deliver anything under the second. Still the connection is but slight, and the case of the nature of Morgan v. McKee (77 $\mathrm{Pa} .229$, supra) rather than Hoare v. Rennie, and a proper subject for the doctrine of breach by anticipation. Besides, the Court does not say a bare refusal to pay would not have been sufficient to justify a rescission of the first contract or of all. It says it is more than a bare refusal; it relates also to all future payments.

'The cases of Tipton $\approx$. Feitner, 20 N. Y. 423 ; Sickell $v$. Pattison, 14 Wendell, 257; Swift v. Opdyke, 43 Barbour 274, Per Lee v. Beebe, 13 Hun. 89 , are all instances of this effect of a severance of performance in a state where, if a contract is entire, the rule that all must be tendered before anything is due has been very stoutly applied. Catlin $v$. Tobias, 26 N. Y. 217.

2 See Part I. 
It would be irksome to cite instances in every jurisdiction. Suffice it to say that with few exceptions throughout the States of the Union, it is now settled law that a contract where the thing sold is to be delivered in installments and corresponding payments made, an orderly part performance gives the right to a proportionate payment without regard to any future performance or breach of the residue. But if either party be guilty of a breach either in delivery or payment, either as to the first or any subsequent portion, then the other party at his option may terminate all of the contract which is still executory, though such termination does not affect the rights already vested by an orderly part performance.

In New Jersey ${ }^{1}$ and Iowa ${ }^{2}$ Lord Blackburn's view in Mersey v. Naylor seems to be followed. The severance of performance makes the contract not merely divisible, but so far separate and independent that a breach as to one can only affect those subsequently to be performed when the circumstances surrounding show it to amount to a breach by anticipation as to them.

Francis $H$. Bohlen.

${ }^{2}$ Gerli v. Poidebard, 57 N. J. Law 432.

${ }^{2}$ Wheeler $v$. Myer, 65 Iowa, 390. 